\title{
PENGUJIAN MUTU TABLET METRONIDAZOL 500 MG GENERIK BERLOGO DAN BERMEREK DAGANG YANG BEREDAR DI WILAYAH PASAR MINGGU JAKARTA SELATAN
}

\author{
Lisawati Tanzil ${ }^{1}$, Suzana Indah Astuti ${ }^{2}$, Siti Rahayu Rachmawati ${ }^{3}$ \\ 1,2,3 Jurusan Analisa Farmasi dan Makanan \\ Politeknik Kesehatan Kementerian Kesehatan Jakarta II \\ Email: sitirahayu.rachmawati@yahoo.co.id
}

\begin{abstract}
Quality Control for Generic Group and Branded Group of Metronidazol Tablets that Bought from Pasar Minggu Area South Jakarta. Quality control for generic group and branded group of metronidazol tablets that bought from Pasar Minggu areas, South Jakarta had been carried out. Three of the samples were belong to the generic group and the other three are from branded group. The purpose of this research was to compare the quality of these two groups that including identification test, dissolution test, assay test and uniformity of dosage units form test. It turned out that both groups fulfill the conditions that stated in The Indonesian Pharmacope $4^{\text {th }}$ edition, it means that both groups have equal quality.
\end{abstract}

Keywords: Tablet, Generic, Branded, Tablet's quality control

\begin{abstract}
Abstrak: Pengujian Mutu Tablet Metronidazol 500 mg Generik Berlogo dan Bermerek Dagang yang Beredar di Wilayah Pasar Minggu Jakarta Selatan. Untuk memasyarakatkan produk obat generik berlogo (OGB) perlu dilakukan pengujian tentang mutu OGB. Tujuan penelitian adalah membandingkan mutu tablet metronidazol $500 \mathrm{mg}$ generik berlogo dan bermerek dagang yang beredar di wilayah Pasar Minggu Jakarta Selatan. Penelitian ini dilakukan terhadap enam sampel yang beredar di wilayah Pasar Minggu Jakarta Selatan, dimana tiga dari keenam sampel tersebut adalah yang termasuk dalam kelompok generik berlogo dan tiga lainnya adalah yang termasuk dalam kelompok bermerek dagang,. Parameter mutu yang diuji adalah uji identifikasi, uji disolusi, uji penetapan kadar dan uji keragaman bobot. Hasil uji menunjukkan bahwa baik kelompok generik berlogo maupun kelompok bermerek dagang memenuhi persyaratan Farmakope Indonesia edisi IV, hal ini menunjukkan bahwa kelompok generik berlogo mempunyai mutu yang setara dengan kelompok bermerek dagang.
\end{abstract}

Kata kunci: Tablet, Generik, Merek dagang, Uji mutu tablet

Obat menurut Tjay dan Raharja (2002) adalah merupakan semua zat baik kimiawi, hewani, maupun nabati yang dalam dosis layak dapat menyembuhkan, meringankan atau mencegah penyakit berikut gejalanya. Sedangkan menurut Anief (2003), obat adalah suatu zat yang digunakan untuk diagnosis pengobatan, melunakkan, menyembuhkan atau mencegah penyakit pada manusia dan pada hewan. Obat merupakan salah satu komponen terbesar pembiayaan terapi suatu penyakit. Ketika seseorang sakit, biaya pengobatan yang mahal sering menjadi keluhan. Untuk menyiasati hal tersebut, Obat Generik Berlogo (OGB), yang harganya lebih murah dibandingkan dengan obat bermerek dagang, dapat dijadikan pilihan. Sayangnya, masih banyak anggapan bahwa OGB memiliki mutu yang rendah dibandingkan obat bermerek dagang. Hal ini dapat dilihat dari jarangnya dokter yang meresepkan OGB dan juga pasien cenderung tidak menyukai jika diresepkan OGB, padahal yang dapat memproduksi OGB hanya perusahaan yang memiliki standar CPOB (Cara Produksi Obat Yang Baik) saja karena dibutuhkan persyaratan dan ketentuan tertentu.

Hasil survei yang dilakukan Indonesian Coruption Watch (ICW) selama bulan November 2009, menunjukkan belum semua pasien Jamkesmas, pemegang kartu keluarga miskin dan surat keterangan tidak mampu, mendapatkan obat generik. Hal ini juga diperkuat berdasarkan data Kementerian Kesehatan tahun 2009 yang menunjukkan terjadi penurunan pasar obat generik sebesar 2,37 triliun rupiah padahal pasar obat nasional naik sebesar 30,56 triliun rupiah (Ine, 2010). 
Program Obat Generik Berlogo ditetapkan dengan Peraturan Menteri Kesehatan No. 085 tahun 1989, peraturan ini mengatur tentang produksi obat generik dan kewajiban menulis resep obat generik pada fasilitas kesehatan milik pemerintah untuk pasien rawat jalan dan rawat inap. Jenis Obat ini mengacu pada Daftar Obat Esensial Nasional (DOEN), yang merupakan obat esensial untuk penyakit tertentu. Untuk lebih mendukung penggunaan obat esensial generik tersebut beberapa ketentuan lainnya juga ditetapkan, seperti SK Menkes No. 988 tahun 2004 tentang Pencantuman Nama Generik pada Label Obat dan SK Menkes No.12 Tahun 2005 tentang Harga Jual Obat Generik.

Salah satu obat yang tersedia baik dalam bentuk OGB dan bermerek dagang adalah tablet metronidazol $500 \mathrm{mg}$, obat ini berkhasiat sebagai antiamubiasis dan antigiardiasis.

Walaupun obat ini tersedia dalam bentuk OGB yang harganya murah, sekitar Rp.150Rp.200.- per tablet tetapi pasien lebih menyukai obat ini dalam bentuk obat bermerek dagangnya yang harganya jauh lebih mahal berkisar antara Rp.425-Rp.6.400.- per tablet. Berdasarkan kenyataan tersebut, maka penelitian ini mengajukan rumusan masalah untuk mengetahui apakah tablet metronidazol $500 \mathrm{mg}$ bentuk Obat Generik Berlogo yang harganya murah dan bentuk bermerek dagang yang harganya lebih mahal memiliki mutu yang setara.

\section{METODE PENELITIAN}

Penelitian dilaksanakan pada bulan Januari sampai April 2010 bertempat di Laboratorium Prodi D-3 Analis Farmasi dan Makanan Politeknik Kemenkes Jakarta II. Dalam penelitian ini sampel yang diuji terdiri dari 3 jenis produk OGB dan 3 jenis produk bermerek dagang tablet metronidazol $500 \mathrm{mg}$ yang dibeli dari apotik yang berada di wilayah Pasar Minggu Jakarta Selatan. Pengambilan sampel berdasarkan pertimbangan kelengkapan tersedianya tablet metronidazol $500 \mathrm{mg}$ OGB dan bermerek dagang (purposive sampling). Pengujian yang dilakukan meliputi: uji identifikasi, uji disolusi, uji penetapan kadar serta uji keragaman bobot (Farmakope Indonesia edisi IV, 1995). Metode analisis yang digunakan untuk uji identifikasi dan uji disolusi yaitu Spektrofotometri UV, pengukuran dilakukan pada panjang gelombang $\pm 277 \mathrm{~nm}$ dengan $\mathrm{HCl} 0,1 \mathrm{~N}$ sebagai pelarut. Uji penetapan kadar menggunakan metode Kromatografi Cair Kinerja Tinggi (KCKT) yang dilengkapi dengan detektor UV $\lambda 254 \mathrm{~nm}$, kolom tipe $R P-18$, fase gerak adalah campuran air dan metanol ( $80: 20)$, laju alir pada kecepatan
1,5 $\mathrm{mL}$ per menit, hasil pengujian setiap parameter dibandingkan dengan persyaratan.

Pengolahan data menggunakan metode Test of Independency dengan menggunakan tabel kontingensi $b \times k, b=$ baris dan $k=$ kolom dengan $\mathrm{b} \geq 2$ dan $\mathrm{k} \geq 2$ (Iqbal, 1999), untuk melihat perbedaan mutu kedua jenis produk obat.

\section{A. Uji Identifikasi}

Identifikasi terhadap sampel dilakukan dengan menggunakan metode spektrofotometri UV, yaitu dengan membandingkan panjang gelombang serapan maksimun antara larutan standar dan larutan uji. Kedua larutan dibuat dengan cara menimbang saksama dan mengencerkannya dengan larutan $\mathrm{HCl} 0,1 \mathrm{~N}$ sampai diperoleh konsentrasi $10 \mathrm{~g} / \mathrm{mL}$. Tahapan kerja uji identifikasi adalah sebagai berikut:

\section{Pembuatan Larutan Uji}

Diambil 10 tablet, ditimbang satu persatu lalu ditimbang secara bersamaan kemudian dihitung bobot rata-ratanya, selanjutnya tablettablet tersebut digerus kemudian ditimbang saksama setara dengan $25 \mathrm{mg}$ metronidazol, dimasukkan ke dalam labu tentukur $25 \mathrm{~mL}$ dan dilarutkan dengan larutan HCL $0,1 \mathrm{~N}$ sampai tanda. Dipipet $1,0 \mathrm{~mL}$ ke dalam labu tentukur $100 \mathrm{~mL}$, ditambahkan HCL $0,1 \mathrm{~N}$ sampai tanda (10 ppm).

\section{Pembuatan Larutan Standar Metronidazol}

Ditimbang saksama $25 \mathrm{mg}$ metronidazol BPFI, dimasukkan ke dalam labu tentukur $25 \mathrm{~mL}$ kemudian dilarutkan dengan $\mathrm{HCl} \quad 0,1 \mathrm{~N}$ sampai tanda. Dipipet $1,0 \mathrm{~mL}$ ke dalam labu tentukur 100,0 mL, ditambahkan HCL 0,1 N sampai tanda (10 ppm).

\section{Pengukuran Serapan secara Spektrofotometri UV}

Larutan uji dan larutan standar diukur serapannya menggunakan spektrofotometer UV dengan larutan HCL 0,1 N sebagai blangko. Dibuat kurva serapan kedua larutan tersebut, bentuk dan letak panjang gelombang terjadinya serapan maksimum kedua kurva dibandingkan. Uji identifikasi dinyatakan memenuhi syarat jika bentuk kurva serapan dan letak panjang gelombang terjadinya serapan maksimum antara larutan uji dan larutan standar sama. Jika hasil uji identifikasi tidak memenuhi syarat, maka pengujian-pengujian lainnya tidak dilakukan, karena sampel yang diuji dinyatakan sebagai obat palsu. 


\section{B. Uji Disolusi}

Uji disolusi dilakukan melalui tahapantahapan berikut:

\section{Pembuatan Media Disolusi}

Media disolusi yang digunakan adalah larutan HCL 0,1 $\mathrm{N}$ yang telah diawaudarakan. Media disolusi digunakan untuk mengisi tabung disolusi(6 tabung@900 mL), mengencerkan filtrat disolusi, membuat larutan standar dan sebagai larutan blangko pada pengukuran spektrofotometri UV.

\section{Pembuatan Kurva Kalibrasi}

Ditimbang $25 \mathrm{mg}$ Metronidazol BPFI, dimasukkan ke dalam labu tentukur $25 \mathrm{~mL}$, dilarutkan dengan media disolusi, ditambahkan media disolusi sampai tepat tanda pada labu. Dari larutan tersebut diambil secara teliti masingmasing $1 \mathrm{~mL}, 2 \mathrm{~mL}, 3 \mathrm{~mL}, 1 \mathrm{~mL}$ dan $1 \mathrm{~mL}$ dimasukkan ke dalam labu tentukur secara berurutan masing-masing $500 \mathrm{~mL}, 500 \mathrm{~mL}, 500$ $\mathrm{mL}, 100 \mathrm{~mL}$ dan $50 \mathrm{~mL}$, diencerkan dengan media disolusi sampai tanda pada labu, sehingga didapatkan larutan standar dengan konsentrasi 2 ppm, 4 ppm, 6 ppm, 10 ppm dan 20 ppm. Kemudian dilakukan pengukuran serapan terhadap larutan baku tersebut dengan metode spektrofotometri UV pada panjang gelombang \pm $277 \mathrm{~nm}$. Dari data yang diperoleh selanjutnya dihitung dan dibuat persamaan kurva kalibrasi. Kurva kalibrasi dihitung berdasarkan persamaan berikut ini.

Persamaan garis regresi $: \mathrm{y}=\mathrm{bx}+\mathrm{a}$

$$
\begin{aligned}
& b=\frac{\sum_{i}\left\{\left(x_{i}-\bar{x}\right)\left(y_{i}-\bar{y}\right\}\right.}{\sum_{i}\left(x_{i}-\bar{x}\right)^{2}} \\
& a=\bar{y}-b \bar{x}
\end{aligned}
$$

$$
r=\frac{\sum_{i}\left\{\left(x_{i}-x\right)\left(y_{i}-\bar{y}\right)\right\}}{\left\{\left[\sum_{i}\left(x_{i}-\bar{x}^{2}\right)\left[\sum_{i}\left(y_{i}-\bar{y}\right)^{2}\right]\right\}^{1 / 2}\right.}
$$

Keterangan :

$\mathrm{y}=$ serapan

$\mathrm{a}=$ slope

$\mathrm{b}=$ intersep

$\mathrm{x}=$ konsentrasi larutan

$\mathrm{r}=$ koefisien korelasi

\section{Proses Disolusi}

Disolusi dilakukan terhadap 6 tablet untuk masing-masing sampel dengan suhu media disolusi $37 \pm 0,5^{\circ} \mathrm{C}$. Digunakan alat tipe 1 (keranjang ) dengan kecepatan putaran $100 \mathrm{rpm}$. Waktu pengujian selama 60 menit. Alat disolusi dirangkai dan disiapkan sedemikian hingga sesuai dengan ketentuan uji disolusi yang tercantum pada Farmakope Indonesia edisi IV (1995).

\section{Pengukuran Serapan Filtrat}

Setelah proses disolusi selesai, filtrat zat aktif yang terlarut selama proses disolusi dengan perkiraan konsentrasi 555,55 ppm $(500 \mathrm{mg} / 900$ $\mathrm{mL}$ ) dari 6 tabung disolusi, masing-masing diambil $\pm 10 \mathrm{~mL}$ ke dalam gelas piala $25 \mathrm{~mL}$. Dipipet masing-masing $1,0 \mathrm{~mL}$ ke dalam labu tentukur $50 \mathrm{~mL}$ dan diencerkan dengan media disolusi sampai tanda pada labu sehingga didapatkan 6 larutan uji dengan konsentrasi \pm $11,1 \mathrm{ppm}$. Setelah itu dilakukan pengukuran serapan dengan spektrofotometer UV pada panjang gelombang $\pm 277 \mathrm{~nm}$. Dihitung kadar zat aktif terlarut tiap tablet dengan menggunakan persamaan kurva kalibrasi. Uji disolusi dinyatakan memenuhi syarat jika dalam waktu 60 menit larut tidak kurang dari $85 \%(Q) \mathrm{C}_{6} \mathrm{H}_{9} \mathrm{~N}_{3} \mathrm{O}_{3}$ dari jumlah yang tertera pada etiket.

\section{E. Uji Penetapan Kadar}

Penetapan kadar dilakukan dengan metode KCKT yang dilengkapi dengan detektor UV $\lambda$ $254 \mathrm{~nm}$ dan kolom $R P-18$ panjang $250 \mathrm{~mm}$, laju aliran diatur lebih kurang 1,5 mL/menit. Tahapan kerja yang dilakukan sebagai berikut:

\section{Pembuatan Fase Gerak}

Fase gerak dibuat dengan mencampurkan air dan metanol dengan perbandingan 80 dan 20, kemudian disaring dan diawaudarakan. Fase gerak digunakan sebagai fase gerak pada sistem KCKT, sebagai pelarut pada pembuatan larutan standar metronidazol dan larutan uji.

\section{Pembuatan Larutan Standar Metronidazol}

Ditimbang saksama $20 \mathrm{mg}$ metronidazol BPFI, kemudian dilarutkan dengan fase gerak dalam labu tentukur $20 \mathrm{~mL}$ sampai tanda pada labu. Dari larutan tersebut dipipet masing-masing $1 \mathrm{~mL}, 2 \mathrm{~mL}, 3 \mathrm{~mL}, 4 \mathrm{~mL}, 5 \mathrm{~mL}$, dimasukkan dalam labu tentukur $10 \mathrm{~mL}$ dan diencerkan dengan fase gerak sampai tanda pada labu, sehingga didapatkan lima macam larutan standar dengan konsentrasi masing-masing 100 ppm, 200 ppm, 300 ppm, 400 ppm dan 500 ppm, 
selanjutnya kelima larutan standar tersebut disaring dengan penyaring kromatografi porositas $0,45 \mathrm{~m}$ ke dalam tabung reaksi.

\section{Pembuatan Larutan Uji}

Ditimbang serbuk tablet setara dengan 15 mg metronidazol (serbuk tablet yang digunakan adalah sama dengan yang digunakan untuk uji identifikasi), masukkan ke dalam labu tentukur $50 \mathrm{~mL}$, ditambahkan metanol $\mathrm{P}$, dikocok secara mekanik sampai serbuk larut, diencerkan dengan metanol P sampai tanda (kadar 300 ppm), lalu disaring dengan penyaring kromatografi porositas $0,45 \mathrm{~m}$ ke dalam tabung reaksi.

\section{Pengukuran Larutan Standar Metronidazol}

Disuntikkan larutan standar metronidazol seri yang telah dibuat sebanyak 20 L ke dalam sistem kromatografi, dari data hasil pengukuran lalu dibuat persamaan kurva kalibrasi. Rumus persamaan kurva kalibrasi sama seperti pada kurva kalibrasi uji disolusi, dengan mengganti nilai y dari serapan menjadi luas area puncak.

\section{Pengukuran Larutan Uji}

Disuntikkan larutan uji yang telah dibuat sebanyak 20 L kedalam sistem kromatografi, kemudian dari data hasil pengukuran dihitung kadar zat uji dengan menggunakan persamaan kurva kalibrasi.

Uji penetapan kadar dinyatakan memenuhi syarat jika tablet mengandung metronidazol, $\mathrm{C}_{6} \mathrm{H}_{9} \mathrm{~N}_{3} \mathrm{O}_{3}$, tidak kurang dari $90,0 \%$ dan tidak lebih dari $110,0 \%$ dari jumlah yang tertera pada etiket.

\section{F. Uji Keragaman Bobot}

Data-data yang diperoleh dari penetapan kadar seperti bobot rata-rata 10 tablet, bobot satuan tablet dan hasil penetapan kadar digunakan untuk perhitungan keragaman bobot. Kadar metronidazol pada tiap tablet (1 sampai 10 tablet) dihitung dengan persamaan di bawah ini.

$$
K_{i}=\frac{B t}{B r} x \frac{P k}{E} \times 100 \%
$$

Keterangan :

$\mathrm{K}=$ kadar metronidazol pada tiap tablet dalam persen

$\mathrm{Bt}=$ bobot satuan tablet $(\mathrm{mg})$

$\mathrm{Br}=$ bobot rata-rata tablet $(\mathrm{mg})$

$\mathrm{P}_{\mathrm{k}}=$ rata-rata kadar metronidazol yang diperoleh dari hasil penetapan kadar (mg)

$\mathrm{E}=$ bobot metronidazol pada etiket sampel $(\mathrm{mg})$
Selanjutnya dibuat rentang nilai kadar dan dihitung Simpangan Baku Relatif (SBR). Rumus perhitungan SBR sama seperti rumus perhitungan SBR pada uji kesesuaian sistem KCKT.

Kriteria penerimaan uji keragaman bobot adalah sebagai berikut: Jumlah zat aktif dalam masing-masing dari 10 satuan sediaan terletak antara $85 \%$ hingga $115 \%$ dari yang tertera pada etiket dan simpangan baku relatif kurang dari atau sama dengan $6 \%$. Jika 1 satuan terletak di luar rentang $85 \%$ hingga $115 \%$ seperti yang tertera pada etiket dan tidak ada satuan terletak di luar rentang $75 \%$ hingga $125 \%$ dari yang tertera pada etiket, atau jika simpangan baku relatif lebih besar dari 6\% atau jika kedua kondisi tidak terpenuhi, dilakukan uji 20 satuan tambahan. Persyaratan dipenuhi jika tidak lebih dari 1 satuan dari 30 satuan terletak di luar rentang $85 \%$ hingga $115 \%$ dari yang tertera pada etiket dan tidak ada satuan yang terletak di luar rentang $75 \%$ hingga $125 \%$ dari yang tertera pada etiket dan simpangan baku relatif dari 30 satuan sediaan tidak lebih dari $7,8 \%$.

\section{HASIL DAN PEMBAHASAN}

\section{Uji Identifikasi}

Uji identifikasi yang dilakukan terhadap sampel tablet metronidazol $500 \mathrm{mg}$ generik berlogo dan bermerek dagang, menggunakan metode spektrofotometri UV yaitu dengan membandingkan spektrum serapan antara larutan standar metronidazol dengan larutan uji. Kedua larutan uji dibuat pada konsentrasi 10 ppm. Kurva spektrum serapan disajikan pada Gambar 1 sampai 3 untuk sampel OGB dan Gambar 4 sampai 6 untuk sampel bermerek dagang. Hasil pengujian menunjukkan bahwa kurva spektrum serapan larutan uji mempunyai bentuk yang sama dengan kurva spektrum larutan standar dan panjang gelombang terjadinya maksimum keenam sampel tersebut sama dengan larutan standar yaitu pada panjang gelombang $277,0 \mathrm{~nm}$. Hal ini membuktikan bahwa keenam sampel tersebut positif mengandung zat aktif metronidazol. Dengan demikian baik sampel OGB maupun bermerek dagang memenuhi persyaratan uji identifikasi. 
416 Jurnal Kesehatan, Volume VII, Nomor 3, November 2016, hlm 412-419

Gambar 1. Kurva spektrum serapan sampel OGB (A)

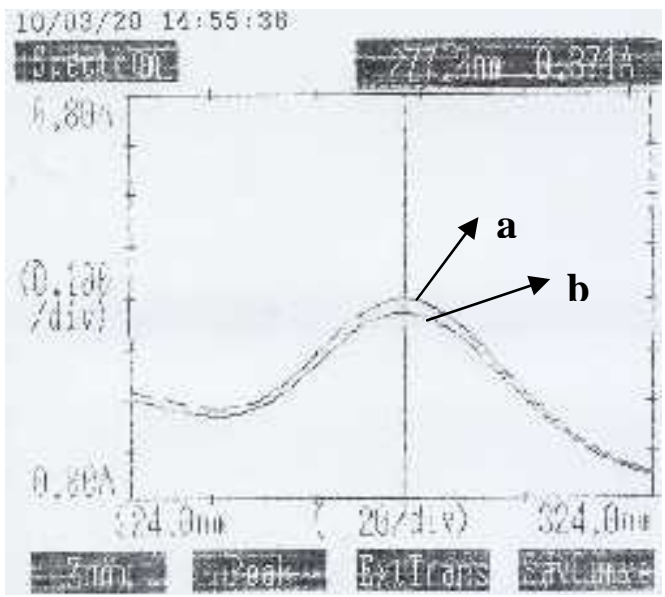

Gambar 2. Kurva spektrum serapan sampel OGB (B)

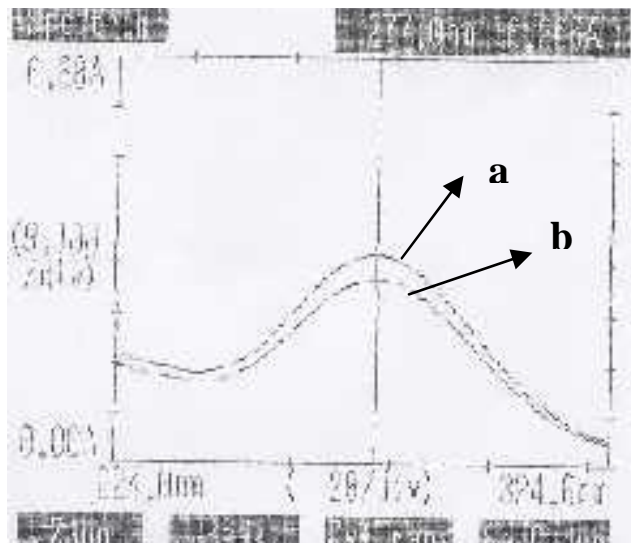

Gambar 3. Kurva spektrum serapan sampel OGB (C)

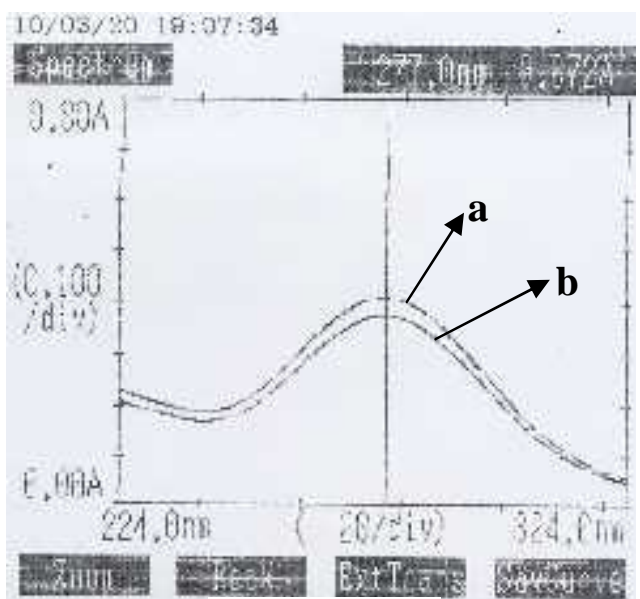

Gambar 4. Kurva spektrum serapan sampel bermerek dagang (D)

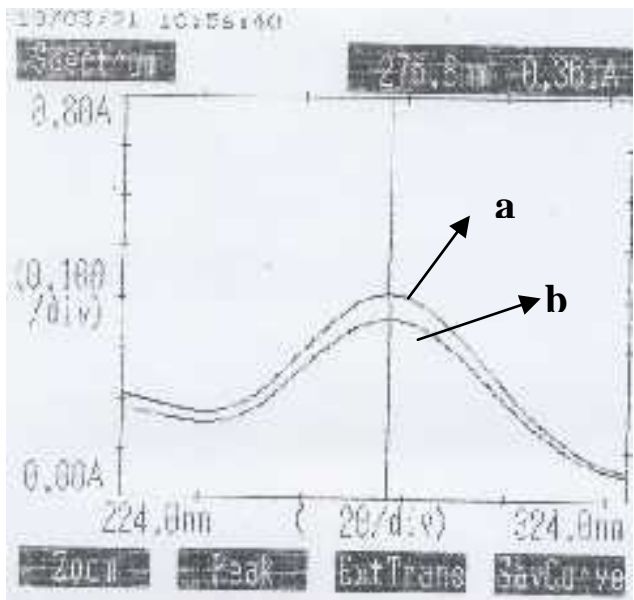

Gambar 5. Kurva spektrum serapan sampel bermerek dagang $(\mathrm{E})$

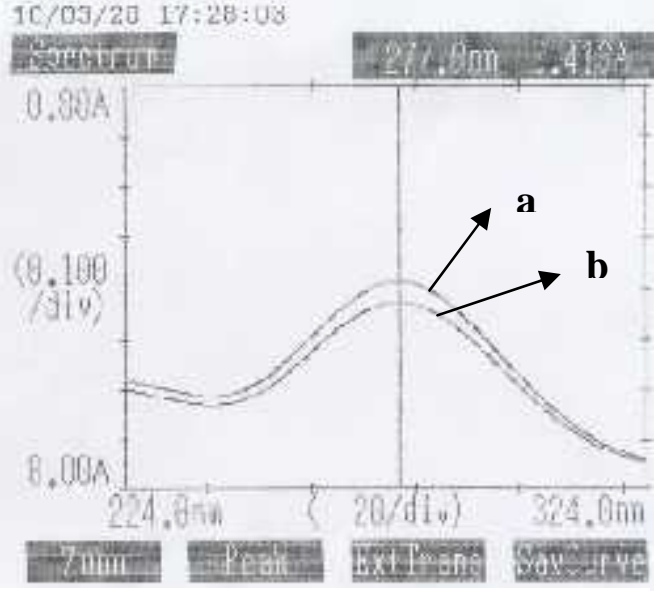

Gambar 6. Kurva spektrum serapan sampel bermerek dagang $(\mathrm{E})$

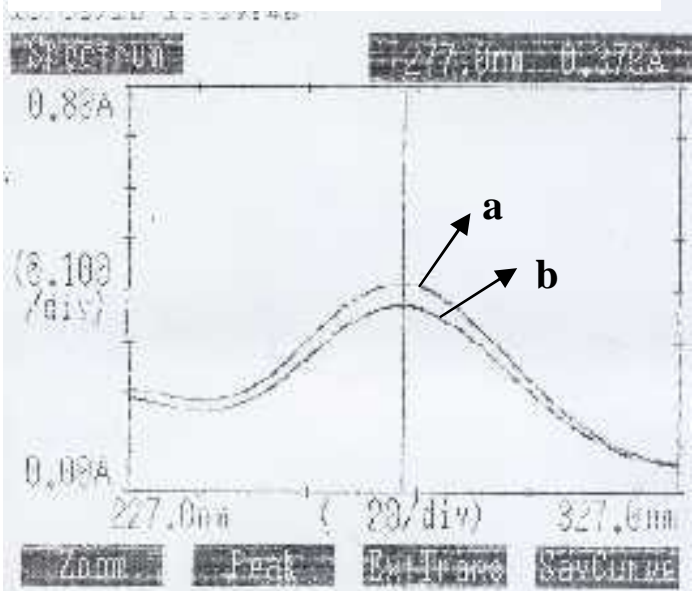

Keterangan: $\quad \mathbf{a}=$ kurva spektrum serapan larutan uji

$\mathbf{b}=$ kurva spektrum serapan larutan standar metronidazol 



\section{Uji Disolusi}

Uji disolusi dilakukan terhadap 36 tablet dimana dari masing-masing sampel diuji 6 tablet. Tipe alat yang digunakan adalah keranjang berputar yang diatur kecepatan putarannya pada 100 RPM. Selama proses disolusi suhu media dipertahankan pada $37 \pm 0,5^{\circ} \mathrm{C}$, dengan waktu 60 menit, kemudian kadar zat aktif terlarut ditetapkan dengan metode spektrofotometri UV pada $\lambda 277,0 \mathrm{~nm}$.

Perhitungan kadar zat aktif terlarut dilakukan dengan menggunakan persamaan kurva kalibrasi yang dibuat menggunakan satu seri larutan standar dengan konsentrasi yang berbeda-beda. Setelah dilakukan pengukuran serapan larutan tersebut, diperoleh sebuah persamaam garis (regresi) $\mathrm{Y}=0,03362 \mathrm{X}+$ 0,0165 dengan koefisien korelasi $(r)=0,9980$. Nilai $r$ yang mendekati 1 membuktikan bahwa metode analisis mampu menunjukkan respon secara langsung atau berbanding lurus terhadap konsentrasi analit dalam sampel, sehingga persamaan regresi di atas dapat digunakan untuk peritungan kadar hasil uji disolusi. Data kurva kalibrasi larutan standar dapat dilihat pada Tabel 1 dan kadar hasil uji disolusi tablet metronidazol $500 \mathrm{mg}$ produk OGB dan bermerek dagang pada Tabel 2.

Tabel 1. Data Kurva Kalibrasi Larutan Standar pada Uji Disolusi

\begin{tabular}{|c|c|}
\hline $\begin{array}{c}\text { Konsentrasi standar } \\
(\mathrm{ppm})\end{array}$ & Absorban \\
\hline 19,92 & 0,744 \\
\hline 9,96 & 0,370 \\
\hline 5,98 & 0,227 \\
\hline 3,98 & 0,150 \\
\hline 1,99 & 0,107 \\
\hline
\end{tabular}

Tabel 2. Kadar Hasil Uji Disolusi Metronidazol $500 \mathrm{mg}$ Produk OGB dan Bermerek Dagang

\begin{tabular}{|c|c|c|c|c|}
\hline \multicolumn{5}{|c|}{ Kadar hasil uji disolusi (\%) } \\
\hline \multirow{7}{*}{ 卷 } & $\begin{array}{c}\text { No. } \\
\text { Tablet }\end{array}$ & Sampel A & Sampel B & Sampel C \\
\hline & 1 & 96,53 & 97,77 & 98,51 \\
\hline & 2 & 95,28 & 96,77 & 96,28 \\
\hline & 3 & 95,28 & 99,01 & 96,03 \\
\hline & 4 & 97,27 & 97,52 & 95,78 \\
\hline & 5 & 95,78 & 99,26 & 97,02 \\
\hline & 6 & 94,29 & 99,26 & 97,77 \\
\hline \multirow{7}{*}{ 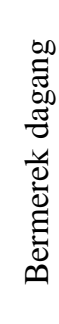 } & $\begin{array}{c}\text { No. } \\
\text { Tablet }\end{array}$ & Sampel D & Sampel E & Sampel F \\
\hline & 1 & 98,51 & 98,02 & 101,25 \\
\hline & 2 & 96,28 & 99,01 & 99,76 \\
\hline & 3 & 96,03 & 98,02 & 100,75 \\
\hline & 4 & 95,78 & 98,02 & 94,54 \\
\hline & 5 & 97,02 & 99,51 & 99,01 \\
\hline & 6 & 97,77 & 97,52 & 98,76 \\
\hline
\end{tabular}

Berdasarkan perhitungan diperoleh kadar hasil uji disolusi terhadap 3 sampel produk OGB berkisar antara 94,29\% sampai 99,26\% dan 3 sampel produk bermerek dagang antara 94,54\% sampai $101,25 \%$. Terlihat tidak ada satupun tablet dari sampel yang diuji yang mempunyai kadar zat aktif terlarut di bawah nilai $90 \%$ (Q + 5\%). Hal ini menunjukkan bahwa uji disolusi terhadap tablet tersebut memenuhi syarat uji disolusi pada tahap S1. Variasi nilai kadar zat aktif terlarut dari tiap tablet dalam sampel yang sama disebabkan oleh perbedaan kecepatan disolusi. Kecepatan disolusi adalah jumlah zat aktif obat dalam sediaan padat yang dapat larut. Menurut Hermini (2007), faktor-faktor yang mempengaruhi kecepatan disolusi adalah sebagai berikut:

1. Faktor teknologi, seperti gaya kompresi dan porositas, jenis mesin tablet dan metode granulasi.

2. Faktor formulasi, seperti jenis dan jumlah zat pengisi, zat pengikat, zat penghancur luar dan dalam serta zat tambahan.

3. Faktor zat aktif, seperti pengaruh ukuran partikel dan kelarutan zat aktif.

4. Faktor yang berhubungan dengan lingkungan disolusi seperti pengadukan, sifat media disolusi yang meliputi $\mathrm{pH}$, suhu, viskositas dan komposisi media disolusi.

\section{Uji Penetapan Kadar}

Uji penetapan kadar dilakukan untuk menjamin bahwa obat yang beredar mengandung zat aktif sesuai dengan kadar yang dipersyaratkan. Hal ini penting untuk tercapainya efek terapi suatu obat. Bila obat mengandung zat aktif melebihi dosis yang ditetapkan maka dapat menyebabkan over dosis, yaitu keadaan yang menyebabkan obat berefek negatif pada pasien. Sedangkan apabila obat mengandungzat aktif kurang dari dosis yang ditetapkan, maka obat tersebut tidak mencapai efek terapinya, bahkan akan timbul efek negatif jika obat tersebut bergolongan antibotika, karena akan timbul resistensi mikroba, sehingga pada terapi berikutnya akan dibutuhkan dosis obat yang lebih besar atau penggantian dengan antibiotik lainnya yang lebih kuat pengaruhnya terhadap mikroba.

Uji penetapan kadar metronidazol dalam sampel tablet dilakukan dengan metode Kromatografi Cair Kinerja Tinggi dengan alat KCKT dilengkapi dengan detektor UV 254,0 nm, kolom C-18 panjang $250 \mathrm{~mm}$, fase geraknya adalah campuran air dan metanol perbandingan 80 dan 20 dengan laju alir $1,5 \mathrm{~mL} / \mathrm{menit}$.

Untuk memastikan bahwa sistem kromatografi dapat digunakan untuk pengujian 
maka dilakukan Uji Kesesuaian Sistem (UKS). Parameter yang diuji dalam UKS adalah presisi dan faktor ikutan (T). Presisi merupakan kedekatan hasil respon dari 5 kali penyuntikan larutan standar secara berurutan dengan jumlah volume penyuntikan dan konsentrasi sama, hasilnya dihitung ke dalam bentuk nilai simpangan baku relatif (SBR). Sedangkan untuk perhitungan faktor ikutan (T), diambil salah satu kromatogram dari uji presisi. Pada penelitian ini, larutan standar metronidazol yang digunakan memiliki konsentrasi 297 ppm dengan volume penyuntikan $20 \mu \mathrm{L}$. Data yang diperoleh dari hasil 5 kali penyuntikan dapat dilihat pada Tabel 3. Simpangan baku yang diperoleh dari 5 kali penyuntikan adalah 0,72 untuk luas area dan 0,20 untuk waktu retensi.

Tabel 3. Data Hasil Penyuntikan Larutan Standar pada UKS

\begin{tabular}{ccc}
\hline No & Luas Area & Waktu Reensi \\
\hline 1 & 1514866 & 5,520 \\
2 & 1509466 & 5,540 \\
3 & 1497531 & 5,535 \\
4 & 1493726 & 5,515 \\
5 & 1480423 & 5,520 \\
\hline Rata-rata & 1501002 & 5,526 \\
\hline SBR & 0,72 & 0,20 \\
\hline
\end{tabular}

Setelah dilakukan pengukuran dan perhitungan terhadap salah satu kromatogram diperoleh nilai faktor ikutan (T) sebesar 1,2. Persyaratan pada monografi tidak lebih besar dari $2 \%$ untuk simpangan baku relatif dan tidak lebih dari 2 untuk faktor ikutan (T), sehingga dapat disimpulkan bahwa alat KCKT sudah siap digunakan untuk pengujian penetapan kadar metronidazol.

Dari hasil uji penetapan kadar didapat kadar rata-rata sampel baik OGB maupun bermerek dagang berada pada rentang 90-110\%, dengan demikian dapat disimpulkan bahwa semua sampel tablet yang diuji memenuhi persyaratan kadar yang ditetapkan Farmakope Indonesia edisi IV.

\section{Uji Keragaman Bobot}

Uji keseragaman sediaan dilakukan dengan tujuan untuk mengetahui apakah tiap tablet mempunyai bobot yang seragam atau tidak. Uji ini penting dilakukan karena bobot tablet berpengaruh terhadap jumlah zat aktif yang terkandung didalammya. Semakin besar perbedaan bobot maka semakin besar pula perbedaan kandungan zat aktifnya. Uji keseragaman bobot dilakukan dengan dua cara yaitu keseragaman kandungan dan keseragaman bobot. Pada penelitian ini digunakan cara keseragaman bobot karena tablet yang diuji memiliki bobot zat aktif lebih besar dari $50 \mathrm{mg}$ dan persentase bobotnya lebih besar dari $50 \%$ bobot satuan sediaan.

Uji keseragaman bobot merupakan pengujian yang tidak terpisah dari uji penetapan kadar karena data-data yang digunakan dalam perhitungan uji keseragaman bobot merupakan data yang diambil dari uji penetapan kadar. Data tersebut meliputi: bobot rata-rata 10 tablet, bobot tiap satuan dari 10 tablet, hasil kadar yang diperoleh serta rentang persyaratan kadar. Data rentang persyaratan kadar digunakan untuk menentukan jenis kriteria dalam perhitungan, apakah digunakan kriteria A atau B. Kriteria A digunakan jika rata-rata dari rentang persyaratan kadar lebih kecil atau sama dengan $100 \%$, sedangkan kriteria B jika lebih besar dari $100 \%$. Pada penelitian digunakan kriteria A karena rentang persyaratan kadar yaitu $90-110 \%$, jika dihitung rata-ratanya $100 \%$. Data hasil uji keseragaman bobot dapat dilihat pada Tabel 4.

Tabel 4. Kadar zat aktif yang terkandung dalam tiap satuan tablet metronidazol $500 \mathrm{mg}$ OGB (sampel 1-3) dan bermerek dagang (sampel 4-6)

\begin{tabular}{rrrrrrr}
\hline No & $\begin{array}{l}\text { Sample } \\
\text { A }(\boldsymbol{\%})\end{array}$ & $\begin{array}{l}\text { Sample } \\
\text { B }(\boldsymbol{\%})\end{array}$ & $\begin{array}{l}\text { Sample } \\
\mathbf{C}(\boldsymbol{\%})\end{array}$ & $\begin{array}{l}\text { Sample } \\
\mathbf{D}(\boldsymbol{\%})\end{array}$ & $\begin{array}{l}\text { Sample } \\
\mathbf{E}(\boldsymbol{\%})\end{array}$ & $\begin{array}{l}\text { Sample } \\
\mathbf{F}(\boldsymbol{\%})\end{array}$ \\
\hline 1 & 98,59 & 98,92 & 91,58 & 98,78 & 96,56 & 95,54 \\
2 & 99,20 & 99,00 & 95,27 & 99,52 & 97,04 & 96,02 \\
3 & 99,40 & 99,19 & 96,04 & 99,62 & 97,06 & 96,49 \\
4 & 99,82 & 99,26 & 96,26 & 99,66 & 97,14 & 96,58 \\
5 & 100,33 & 99,27 & 96,98 & 99,66 & 97,70 & 96,66 \\
6 & 100,44 & 99,32 & 97,38 & 99,70 & 97,81 & 97,22 \\
7 & 100,45 & 99,94 & 98,46 & 100,21 & 97,99 & 97,47 \\
8 & 100,59 & 100,7 & 98,91 & 100,36 & 98,71 & 97,59 \\
9 & 101,05 & 100,83 & 99,77 & 100,54 & 98,75 & 97,62 \\
10 & 101,90 & 101,30 & 101,9 & 100,70 & 99,53 & 98,42 \\
\hline SBR & 0,96 & 0,87 & 2,89 & 0,57 & 0,96 & 1,66 \\
\hline
\end{tabular}

Hasil uji keragaman bobot diperoleh bahwa kadar zat aktif dari tiap sampel baik OGB maupun bermerek dagang tidak ada yang di luar rentang $85 \%-115 \%$ dan nilai simpangan baku relatifnya jauh di bawah $6 \%$, sehingga dapat disimpulkan bahwa sampel yang diuji memenuhi syarat uji keragaman bobot. Menurut Lachman et al. (1994), keseragaman isi tablet dapat dipengaruhi oleh tidak seragammnya distribusi bahan obat pada pencampuran bubuk atau granulasi dan pemisahan dari campuran bubuk atau granulasi selama berbagai proses pembuatan.

Untuk mengetahui apakah ada perbedaan mutu antara tablet metronidazol $500 \mathrm{mg}$ produk OGB dan bermerek dagang telah dilakukan uji hipotesis. Uji yang digunakan adalah Hipotesis Independensi (Test of Independency) (Iqbal, 
1999), dimana pada uji hipotesis ini sampel dikelompokkan menjadi 2 kriteria yaitu Memenuhi Syarat dan Tidak Memenuhi Syarat. Memenuhi syarat artinya bahwa sampel yang diuji memenuhi semua persyaratan dari 4 pengujian yang dilakukan yaitu uji identifikasi, uji disolusi, uji penetapan kadar dan uji keragaman bobot, sedangkan tidak memenuhi syarat artinya ada salah satu atau lebih dari 4 pengujian yang persyaratannya tidak terpenuhi.

Dari hasil pengujian terhadap sampel 3 tablet metronidazol $500 \mathrm{mg}$ OGB dan 3 sampel tablet metronidazol $500 \mathrm{mg}$ bermerek dagang dapat disimpulkan bahwa semuanya memenuhi persyaratan. Data-data tersebut kemudian diubah ke dalam bentuk tabel silang hubungan antara jenis produk dengan terpenuhinya syarat mutu antara tablet metronidazol $500 \mathrm{mg}$ OGB dan bermerek dagang. Hasil uji Test of Independency dapat dilihat pada Tabel 5. Formulasi hipotesis yang diajukan pada penelitian adalah sebagai berikut : $\mathrm{H}_{\mathrm{o}}$ : tidak ada perbedaan mutu antara tablet metronidazol $500 \mathrm{mg}$ produk OGB dan bermerek dagang, $\mathrm{H}_{1}$ : ada perbedaan mutu antara tablet metronidazol $500 \mathrm{mg}$ produk OGB dan bermerek dagang. Taraf nyata $(\alpha)$ dan nilai $\chi^{2}$ tabelnya dengan $\mathrm{db}=1, \mathrm{~A}=1 \%=0,01 \mathrm{db}=1$, $\chi_{0,01(1)}^{2}=6,635$. Sehingga kriteria pengujian hipotesis menjadi sebagai berikut ini : $\mathrm{H}_{\mathrm{o}}$ diterima apabila $\chi_{0}^{2} \leq 6,635, \mathrm{H}_{1}$ diterima apabila $\chi_{0}^{2}>6,635$. Uji statistik dihitung dengan persamaan berikut ini.

$$
\begin{aligned}
& \lambda_{o}^{2}=\frac{n\left(|a d-b c|-\frac{1}{2} n\right)^{2}}{(a+b)(a+c)(b+d)(c+d)} \\
& \lambda_{o}^{2}=\frac{6(|0-0|-3)^{2}}{(3)(6)(0)(3)} \\
& \chi_{o}^{2}=1
\end{aligned}
$$

Dari hasil perhitungan di atas diperoleh nilai $\chi_{0}^{2}=1$, nilai ini lebih kecil dari 6,635, sehingga $\mathrm{H}_{\mathrm{o}}$ diterima. Karena $\mathrm{H}_{\mathrm{o}}$ diterima maka dapat disimpulkan bahwa tidak ada perbedaan mutu antara tablet metronidazol $500 \mathrm{mg}$ produk OGB dan bermerek dagang.

\section{SIMPULAN}

Berdasarkan hasil pengujian didapatkan sampel tablet metronidazole $500 \mathrm{mg}$ OGB dan bermerek dagang memenuhi persyaratan parameter uji Farmakope Indonesia edisi IV (1995) yang meliputi: uji identifikasi, uji disolusi, uji penetapan kadar dan uji keragaman bobot sehingga dapat disimpulkan bahwa tablet metronidazol $500 \mathrm{mg}$ OGB mempunyai mutu yang setara dengan tablet metronidazol $500 \mathrm{mg}$ bermerek dagang.

\section{SARAN}

Masyarakat diharapkan tidak ragu lagi terhadap mutu obat tablet metronidazol $500 \mathrm{mg}$ OGB karena telah terbukti bahwa mutu tablet metronidazol $500 \mathrm{mg}$ OGB setara dengan mutu tablet metronidazol $500 \mathrm{mg}$ bermerek dagang.

\section{DAFTAR PUSTAKA}

Anief, M. 2003. Apa yang Perlu Diketahui tentang Obat. Cetakan Ke-4, hlm. 3-7. Jogjakarta: Gadjah Mada University Press.

Iqbal H., M. 1999. Pokok-Pokok Materi Statistik 2. Cetakan Ke-1, hlm. 191-196. Jakarta: Bumi Aksara.

Ine. 2010. Obat Generik Diabaikan Konsumen Banyak Dirugikan. Kompas. 22 Pebruari 2010. hal. 1 kolom 2.
Lachman, L., Lieberman, H.A dan Kanig, J.L. 1994. Teori dan Praktek Farmasi Industri II. Edisi Ke-3. Hlm. 657. Jakarta: UI Press.

Tjay, T. H. dan K. Raharja. 2002. Obat-Obat Penting, Khasiat, Penggunaan dan Efekefek Sampingnya. Edisi Ke-5. Hlm. 3. Jakarta: Elex Media Komputindo. 